\title{
EXPRESSION SHAPING PADA ANAK MELALUI AKTIVITAS SOSIODRAMA
}

\author{
Wulan Patria Saroinsong ${ }^{1}$, Irma Novita Agni Putri ${ }^{2}$ \\ Fakultas Ilmu Pendidikan, Universitas Negeri Surabaya ${ }^{1}$ \\ Fakultas Ilmu Pendidikan, Universitas Negeri Surabaya ${ }^{2}$ \\ Email: wulanpatria@unesa.ac.id ${ }^{1}$, Email: irmaputri16010684058@mhs.unesa.ac.id ${ }^{2}$ \\ Saroinsong, Wulan Patria. (2020). Expression Shaping Pada Anak Melalui Aktivitas Sosiodrama. Jurnal Pelita \\ PAUD, 4(2), 208-213. \\ doi: https://doi.org/10.33222/pelitapaud.v4i1.984
}

Diterima:27-05-2020

Disetujui: 01-06-2020

Dipublikasikan: 11-06-2020

Abstrak: Penelitian ini bertujuan untuk mengetahui aktivitas sosiodrama dalam pengungkapan ekspresi bahasa anak usia $5-6$ tahun. Penelitian ini menggunakan jenis penelitian kuantitatif dengan rancangan expost facto. Subjek pada penelitian ini sebanyak 32 guru dan 32 orang tua anak di TK Surabaya. Pengumpulan data pada penelitian ini melalui kuisioner online yang disebar menggunakan google form. Analisis data pada penelitian ini menggunakan analisis regresi linier sederhana. Berdasarkan hasil perhitungan, studi ini menemukan bahwa metode sosiodrama berkontribusi positif terhadap kemampuan bahasa, terutama pada jumlah kosakata yang diucapkan anak untuk mengekspresikan perasannya. Hal ini menunjukkan bahwa ada pengaruh metode sosiodrama terhadap kemampuan bahasa anak. Penelitian ini memberikan implikasi terhadap orang tua dan guru dalam menstimulasi kemampuan bahasa anak, terlebih pada kosakata yang berkaitan dengan pengungkapan ekspresi dan perasaan pada anak.

Kata Kunci: Expression Shapping, Bahasa, Sosiodrama, Anak Usia Dini

Abstract: This study aimed to determine of the socio-drama activity in the language expression of children had age 5-6 years. This research used quantitative research with expost-facto design. Subjects in this study were 32 teachers and 32 children's parents in Surabaya kindergarten. Collecting data in this study through questionnaires online distributed using Google forms. Data analysis in this study used simple linear regression analysis. Based on the results of the calculation, this study found that the socio-drama method positively contributed for children's languange skills, especially the amount of vocabulary spoken by children to express their feelings. This showed that there was an influence of the socio-drama method on children's language skills. This research had implications for parents and teachers in stimulating children's language skills, especially in vocabulary related to the expression of feelings and feelings in children.

Keywords: Expression Shapping, Language, Socio-drama, Early Childhood 


\section{PENDAHULUAN}

Anak usia dini yaitu anak pada tahapan usia 0-6 tahun, pada tahapan usia ini disebut sebagai usia emas (golden age) dimana anak memiliki sifat aktif dan rasa ingin tahu yang tinggi (Sujiyono, 2013). Pada rentang usia $3-6$ tahun adalah masa anak memasuki masa pra-sekolah yang merupakan masa persiapan untu memasuki pendidikan formal. Masa ini adalah masa peka terhadap segala stimulasi yang diterima melalui panca indera anak, sehingga dalam pengembangan enam aspek perkembangan pada anak harus diberikan, pemberian stimulasi yang baik akan mengalami tumbuh kembang yang baik sesuai tahapan usianya.

Salah satu aspek yang sangat penting untuk diperhatikan di keluarga, sekolah, maupun lingkungan masyarakat adalah perkembangan bahasa. Aspek yang berkaitan pada perkembangan bahasa yaitu kosakata, sintaksis, dan semantik. Kosakata merupakan dasar atau pondasi yang diperlukan untuk keterampilan berbahasa. (Stone, 2013: 127) mengatakan bahwa kosakata sangatlah penting bagi keberhasilan membaca dan pemahaman bahasa anak, semakin banyak kata yang dimiliki anak, semakin banyak kata-kata yang akan dikenali saat anak membaca maupun berbicara. Bahasa merupakan salah satu unsur yang melandasi aspek perkembangan yang ada pada anak usia dini. Hal ini karena bahasa merupakan bekal dasar bagi anak dalam berkomunikasi dengan masyarakat.

Pentingnya bahasa sebagai alat atau sarana untuk berkomunikasi dengan sesama atau lingkungan sekitarnya, karena bahasa merupakan dasar pertama yang paling berurat dan berakar pada lingkungan masyaratat (Rakhmawati, 2015:5). Bahasa adalah sarana komunikasi yang menyimbolkan pikiran dan perasaan untuk menyampaikan makna kepada orang lain (Hurlock, 2013: 176). Pada kehidupan seharihari, bahasa sangat dibutuhkan dalam berkomunikasi karena individu selalu berinteraksi dengan lingkungan. Bahasa menjadi sistem komunikasi antar manusia. Karena dengan berbahasa kita bisa tau apa yang diinginkan orang lain, sebaliknya apa yang kita inginkan dapat tersampaikan. Bahasa digunakan anak dalam kehidupan sehari - hari untuk melaksanakan interaksi kepada orang lain. Seperti yang diungkapkan (Dhieni dkk, 2014: 2.21) bahasa adalah pengungkapan maksud, tujuan, pemikiran, dan perasaan kepada orang lain. Bentuk-bentuk kemampuan berbahasa yang diungkapkan (Otto, 2015:17) meliputi kemampuan bahasa lisan dan kemampuan bahasa tulis. Contoh kegiatan kemampun bahasa lisan pada anak, bentuk reseptifnya dengan kegiatan mendengarkan cerita dan bentuk ekspresifnya dengan kegiatan menceritakan tentang kejadian dirumah. Seperti dalam bentuk kemampuan bahasa tulis pada anak yaitu bentuk reseptifnya dengan kegiatan membaca buku cerita dan bentuk ekspresifnya dengan kegiatan menuliskan makanan dan minuman yang disukai. Hal ini kemampuan bahasa perlu dikembangkan agar bisa ekspresi dan perasaan anak dapat diungkapkan.

Pengembangan bahasa pada anak usia dini memiliki tujuan yang diungkapkan Early Learning Goals (Susanto, 2017: 79) sebagai berikut: anak lebih siap untuk menyimak dan menggunakan bahasa yang mudah saat belajar dan bermain bersama-sama, anak mengenal kosakata sederhana dengan mudah, anak mencoba untuk menulis sesuai apa yang diinginkan dan kosakata anak bertambah banyak dan mampu dimengerti oleh anak, anak mampu menyampaikan expresi dan perasaan yang diungkapkan, anak mampu mendengar dan memberikan apresiasi pada cerita dan lagu yang didengar, anak mampu mencari terhadap kosakata yang diberikan, anak mampu memberikan apresiasi dengan berbagai pernyataan atau komentar, anak mampu bersosial dengan orang lain dan merencanakan kegiatan bersama teman, anak mampu menceritakan kegiatan yang telah dialami sesuai urut. Berdasarkan hasil observasi yang dilakukan peneliti di TK Surabaya Selatan lebih tepatnya di Kelurahan Wonokromo yang berlokasi di daerah Jetis Kulon ditemukan masalah yang sering dihadapi pada anak adalah ketika anak-anak berkomunikasi, banyak anak yang kurang mengerti dan berbahasa dengan baik saat menyampaikan apa yang anak rasakan. Dengan keadaan tersebut kegiatan belajar mengajar menjadi terhambat. Dari data yang didapat kemampuan bahasa mengalami penurunan dan termasuk dikategorikan rendah dibandingkan aspek kemampuan lainnya. Pembelajaran untuk mengembangkan kemampuan bahasa anak masih berpusat pada guru dengan metode tanya jawab dan hanya terbatas LKA saja. Padahal kemampuan berbicara tidak hanya sebatas LKA, akan tetapi dengan stimulasi lewat percakapan antara guru dengan murid atau anak dengan anak. Hal ini akan dapat membantu mengembangkan kemampuan berbicara anak. Seperti yang dikemukakan oleh (Dhieni dkk, 2014: 3.6) bahwa belajar berbicara dapat dilakukan anak dengan bantuan dari orang dewasa melalui 
Vol. 4 No. 2 Juni 2020

percakapan, dengan bercakap - cakap anak akan mengemukan pengalaman, meningkatkan pengetahuan dan mengembangkan bahasanya. Sebuah pembelajaran dapat dikatakan berhasil apabila anak terlibat langsung secara emosional dan intelektual dalam proses pembelajaran, anak memperoleh informasi dengan aktif. Kriteria/ perspektif pembelajaran yang sukses adalah peran aktif anak. Salah satu metode pembelajaran yang berpusat pada siswa adalah metode sosiodrama, karena metode ini membutuhkan keaktifan anak di depan kelas secara bersama-sama.

Berdasarkan hal tersebut, peneliti berupaya menerapkan metode sosiodrama untuk menstimulasi kemampuan bahasa anak. Pendapat yang diungkapkan (Sudjana, 2014: 76), menjelaskan sosiodrama adalah cara mengajar yang memberi kesempatan pada anak untuk melakukan kegiatan memainkan peran tertentu, seperti yang terdapat dalam kehidupan masyarakat. (Beaty, 2015: 420) juga menegaskan bahwa permainan drama dapat membantu anak dalam mengembangkan kemampuan sosial, intelektual, bahasa dan kreativitas. Jadi, dapat diartikan metode sosiodrama merupakan metode pembelajaran dengan mendramatisasikan tingkah laku manusia, yang melibatkan interaksi antara dua orang atau lebih tentang suatu tema yang akan diperankan, sehingga menjadikan pembelajaran menjadi lebih menyenangkan dan berkesan dan dapat mengembangkan kemampuan sosial, intelektual, bahasa dan kreativitas.

Metode sosiodrama memiliki tujuan dalam kegiatan bermain anak. (Goyena \& Fallis, 2019) tujuan anak bermian dalam konteks sosiodrama adalah: 1) Anak memiliki kemmapuan untu memahami dan menghayati perasaan teman dan lingkungannya. 2). Anak memahami tanggung awabnya sebagi seorang anak, siswa dan teman sesuai dengan konteks perannya. 3) Menstimulais kemampuan kosakata, interaksi sosial, dan kreativitas anak. 4). Anak memahami peer learning. 5). Menstimulasi suasana kelas untuk fokus pada pemecahan masalah. 6) naak akan mengalami vocabulary improvement. Kegiatan sosiodrama di Taman Kanak-kanak menjadi pembelajaran yang menarik dan menyenangkan, anak juga belajar berbicara sesuai dengan peran yang dimainkan, belajar mendengarkan dengan baik, dan melihat hubungan antara berbagai peran yang dimainkan. Oleh karena itu dalam penerapan metode sosiodrama memiliki langkah-langkah tertentu yang memberikan ciri khas terhadap metode itu sendiri. Shaftel (Tarnoto, 2013) mengemukakan tahapan melakukan sosiodrama, yaitu: 1) Guru menetapkan topik atau masalah serta tujuan yang akan dicapai. 2).
Guru memberikan gambaran masalah dalam situasi yang akan dimainkan. 3) Guru menjelaskan aturan main. 4) Guru menciptakan suasana yang dapat memotivasi anak. 5) Memilih peran. 6) Menyusun tahapan bermain peran. 7) Mulai dimainkan oleh kelompok pemeran. 8) Guru menarik perhatian anak. 9) Guru hendaknya memberikan bantuan kepada pemeran yang mendapat kesulitan 10) Bermain peran dihentikan pada saat puncak. Hal ini dimaksudkan untuk mendorong anak berpikir dalam menyelesaikan masalah yang sedang diperankan. 11) Melakukan diskusi tentang peran yang dimainkan.

Beberapa penelitian membuktikan bahwa metode sosiodrama berdampak positif terhadap kemampuan bahasa anak. Penelitian (Fatimah et al., 2019) tentang peran guru dalam melakukan scaffolding pada aktivitas bermain sosiodrama yang dilaksanakan pada anak prasekolah menunjukkan bahwa anak prasekolah terdapat minat yang lebih besar dalam bermain sosiodrana dibandingkan kegiatan yang lain yang biasa dilakukan di kelas. Peneliti lain oleh Sudarma dan Garminah (2014) menunjukkan bahwa hasil dari sosiodrama berbantuan cerita rakyat dapat meningkatkan keterampilan kemampuan berbahasa anak. Penelitian Pelletier (2011) menunjukkan bahwa permainan sosiodrama mampu meningkatan kemampuan bahasa anak. Berdasarkan latar belakang permasalahan diatas, tujuan penelitian adalah untuk mengetahui aktivitas sosiodrama dalam pembentukan ekspresi bahasa anak usia $5-6$ tahun.

\section{METODE PENELITIAN}

Penelitian tentang Expression Shaping Pada Anak Melalui Aktivitas Sosiodrama menggunakan penelitian kuantitatif, dimana data berupa angka dan dianalisis menggunakan data statistik. Jenis penelitian ini menggunakan metode korelasi dengan desain rancangan expost facto, yakni penelitian yang bertujuan mengekspos kejadian-kejadian yang sedang berlangsung (Jogiyanto, 2014: 58).

Populasi dalam penelitian ini yaitu guru dan orang tua anak usia 5-6 tahun di Taman Kanak-kanak Kota Surabaya yang menerapkan metode sosiodrama. Dalam penelitian ini, peneliti menggunakan sampel 33 guru dan 33 orang tua di Taman Kanak-kanak Kota 
Vol. 4 No. 2 Juni 2020

Surabaya. Sampel penelitian ini menggunakan teknik purposive sampling untuk mengetahui seberapa besar metode sosiodrama dalam kemampuan bahasa anak.

Teknik pengumpulan data pada peneltian ini menggunakan teknik kuisioner online yang berbentuk link berupa google form dan mampu diakses oleh siapa saja. Dan memberikan sejumlah butir pertanyaan tentang seberapa kontribusi metode sosiodrama yang diterapkan di Taman Kanak-kanak. Kuisioner yang digunakan menggunakan kuisioner tertutup sehingga jawaban sudah tersedia dan responden tinggal memilih jawabannya. Dalam penelitian ini menggunakan rating scale dengan menjabarkan variabel yang diukur menjadi indikator variabel. Untuk pengumpulan data variabel $\mathrm{X}$ menggunakan kuisioner persepsi dan variabel $\mathrm{Y}$ menggunakan kuisioner feedback.

Teknik analisis data pada penelitian ini dilakukan dari tahap uji validitas, uji reliabilitas, uji normalitas, dan uji homogenitas. Selanjutnya dilakukan analisis data menggunakan uji hipotesis berupa regresi linier sederhana dengan tingkat kepercayaan 95\% $(\mathrm{a}<0,05)$ menggunakan software IBM SPSS versi 22. Uji hipotesis bertujuan untuk menentukan ada tidaknya pengaruh metode sosiodrama terhadap kemampuan bahasa anak usia 5 - 6 tahun. Berdasarkan rumusan masalah dan hipotesis yang digunakan untuk mengkaji hipotesis pada penelitian ini menggunakan analsisi regresi sederhana, (Sugiyono, 2011:261).

Untuk menjawab hipotesis maka pengambilan keputusan analisis regresi sebagai berikut:

1) Jika nilai sig >0,05, maka Ho diterima dan $\mathrm{Ha}$ ditolak artinya tidak ada hubungan antara metode sosiodrama terhadap kemampuan bahasa anak usia 5 - 6 tahun di TK Surabaya.

2) Jika nilai sig < 0,05 maka maka Ho ditolak dan Ha diterima artinya ada hubungan antara metode sosiodrama terhadap kemampuan bahasa anak usia 5 - 6 tahun di TK Surabaya.

\section{HASIL PENELITIAN DAN PEMBAHASAN}

Hasil penelitian ini dilakukan menggunakan kuisioner online yang disebar ke 64 partisipan yang terdiri 32 guru dan 32 orang tua. Pengisian kuisioner diisi oleh guru dan orang tua anak secara online melalui google form, sehingga guru bisa mengisi 11 pertanyaan seputar metode sosiodrama dan orang tua mengisi 11 pernyataan seputar kemampuan bahasa anak. Perhitungan uji validitas ini menggunakan software IBM SPSS versi 22. Uji validitas pada penelitian ini menggunakan rumus korelasi product moment. Uji validitas pada masing-masing butir item pertanyaan metode sosiodrama dan masing-masing butir indikator kemampuan bahasa dinyatakan valid, karena pada masing-masing item memiliki nilai $r$ diatas 0,349 . Nilai $r_{\text {hitung }}$ pada masing-masing butir pertanyaan $>$ dari $r_{\text {tabel }}$ (0,349). Pada tabel tersebut nilai $r_{\text {hitung }}>$ $r_{\text {tabel }}$ sehingga data yang diperoleh yaitu masing-masing no item pernyataan dan butir indikator dinyatakan valid. Uji reliabilitas pada penelitian ini menggunakan rumus cronbach' alpha dengan hasil variabel persepsi $(0,720)$ dan variabel feedback $(0,772)$ menunjukkan bahwa nilai koefisien cronbach' alpha metode sosiodrama dan kemampuan bahasa diatas 0,6 yang artinya reliabel. Berdasarkan uji normalitas kolmogrov-smirnov diperoleh nilai Asymp sig sebesar 0,132 lebih besar 0,05, maka data tersebut berdistribusi normal. Hasil uji homogenitas menyatakan data variabel bahasa adalah homogen. Begitupun dengan hasil uji linier menyatakan bahwa terdapat hubungan linier antara variabel metode sosiodrama (X) dan variabel bahasa (Y). Setelah dilakukan Uji Asumsi Klasik, maka dilanjutkan dengan analisis regresi yang menyatakan bahwa terdapat pengaruh yang signifikan antara variabel $\mathrm{X}$ terhadap variabel Hasil analisis regresi linier sederhana menunjukkan bahwa ada kontribusi metode sosiodrama terhadap expression shaping atau pembentukan ekspresi pada anak. Hal ini menunjukkan anak dapat mengekspresikan perasaannya melalui kosakata yang diperankan dalam sosiodrama. Berikut hasil dari pengujian analisis regresi linier sederhana.

Tabel 1. Analisis Regresi Analisis Sederhana

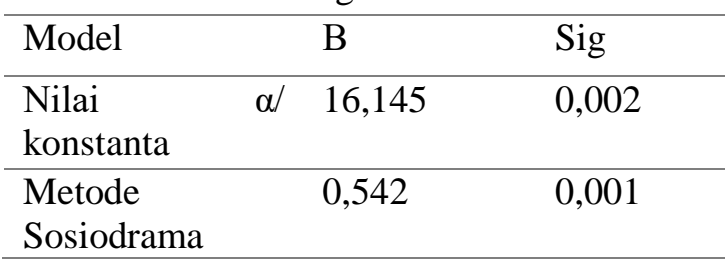

(Sumber: Output SPPS 22)

Pada tabel pertama menyajikan uji analisis regresi sederhana untuk mengetahui dampak variabel $\mathrm{X}$ (metode sosiodrama) terhadap variabel Y (Kemampuan Bahasa).

$$
\begin{aligned}
& Y=a+b x \\
& Y=16,461+0,542 X
\end{aligned}
$$

Gambar 2.Persamaan Regresi Linier Sederhana

Persamaan tersebut dapat diintrepetasikan 
Vol. 4 No. 2 Juni 2020

bahwa nilai $\alpha$ sebesar 16,461 dan setiap $1 \%$ perubahan metode sosiodrama, maka nilai kemampuan bahasa bertambah 0,542. Koefisien regresi tersebut bernilai positif, maka arah pengaruh sosiodrama terhadap kemampuan bahasa anak adalah positif, yaitu setiap pemberian metode sosiodrama pada anak menyebabkan kemampuan bahasa anak meningkat. Pengambilan keputusan berdasarkan nilai (sig.) < 0,05 Ho ditolak sedangkan jika nilai (sig.) $>0,05$ Ho diterima. Terihat pada tabel kedua bahwa nilai (sig.) 0,001 >0,05, maka Ho dapat ditolak dah Ha diterima, yang artinya ada dampak metode sosiodrama pada kemampuan bahasa anak usia 5-6 tahun. Berdasarkan hasil analisis regresi linier sederhana menunjukkan kegiatan pembelajaran menggunakan metode sosiodrama mempunyai hubungan positif dan signifikan pada aspek kemampuan bahasa anak usia dini. Hasil tersebut sesuai dengan pendapat (Dhieni, dkk, 2014:3.6) bahwa belajar berbicara dapat dilakukan anak dengan bantuan dari orang dewasa melalui percakapan, dengan bercakap - cakap anak akan mengemukan pengalaman, meningkatkan pengetahuan dan mengembangkan bahasanya. Beaty (2015: 420) juga menegaskan bahwa permainan drama dapat membantu anak dalam mengembangkan kemampuan sosial, intelektual, bahasa dan kreativitas. Hasil penelitian ini sejalan dengan yang diungkapkan oleh Pelletier (2011) menunjukkan bahwa permainan sosiodrama mampu meningkatan kemampuan bahasa anak. Penelitian relevan yang dilakukan oleh (Trisnawaty, 2017) menyatakan bahwa terdapat metode sosiodrama melalui script cerita rakyat mampu meningkatkan kemampuan bahasa anak. Pada konsep tersebut memiliki persmaan persepsi danhasil dengan penelitian saat ini, dimana metode sosiodrama dapat menstimulasi kemampuan bahasa pada anak terutama pada aspek ekspresi perasaan. Terkait dengan persamaan hasil penelitian tersebut, faktor lain yang membuat penelitian ini unik adalah contekstual learning yang di blended kedalam model sosiodrama. Kontekstual yang di gunakan berkaitan dengan kegiatan pada umumya yang di alami dan di kerjakan oleh anak. Sehingga anak lebih mudah memahami makna kosakata pada script tersebut sedangkan perbedaannya pada desain penelitian yang menggunakan quasi experiment dan expost facto. Adapun pada penelitian ini menggunakan metode sosiodrama dengan contextual script, sehingga fokus pada kejadian yang dialami anak seperti perasaan anak ketika sakit, sedih, dan sebagainya. Hal ini akan melatih anak untuk beljar asertif dalam mengakspresikan perasaan anak. kontribusi lainnya terdapat pada kenyamanan anak dalam mengenali kosakata yang ada ada pada metode studi ini.. Maka metode sosiodrama digunakan pada penelitian ini sebagai metode untuk meningkatkan bahasa anak dimana terjadi interaksi didalamnya. Hal ini tebukti metode sosiodrama dapat meningkatkan aspek bahasa anak dengan mengekspresikan perasaannya melalui kosakata yang diperankan.

\section{SIMPULAN}

Permasalahan kemampuan bahasa terletak pada metode pembelajaran yang bersifat konvensional contohnya pemberian tugas kepada anak melalui LKA. Hal ini memberikan ide bagi penelitian saat ini untuk mengembangkan kreativitas guru melalui metode sosiodrama. Metode ini efektif untuk mnestimulasi anak dalam mendapatkan kosakata yang tepat dalam mengekspresikan perasaanya. Hal ini sesuai dengan hasil penelitian saat ini, dimana kuisioner online yang disebar ke 64 partisipan yang terdiri atas guru dan orang tua. Penelitian relevan yang dilakukan oleh (Trisnawaty, 2017) menyatakan bahwa terdapat metode sosiodrama melalui script cerita rakyat mampu meningkatkan kemampuan bahasa anak. Pada konsep tersebut memiliki persmaan persepsi danhasil dengan penelitian saat ini, dimana metode sosiodrama dapat menstimulasi kemampuan bahasa pada anak terutama pada aspek ekspresi perasaan. Terkait dengan persamaan hasil penelitian tersebut, faktor lain yang membuat penelitian ini unik adalah contekstual learning yang di blended kedalam model sosiodrama. Kontekstual yang di gunakan berkaitan dengan kegiatan pada umumya yang di alami dan di kerjakan oleh anak. Sehingga anak lebih mudah memahami makna kosakata pada script tersebut sedangkan perbedaannya pada desain penelitian yang menggunakan quasi experiment dan expost facto. Adapun pada penelitian ini menggunakan metode sosiodrama dengan contextual script, sehingga fokus pada kejadian yang dialami anak seperti perasaan anak ketika sakit, sedih, dan sebagainya. Hal ini akan melatih anak untuk beljar asertif dalam mengakspresikan perasaan 
Vol. 4 No. 2 Juni 2020

anak. kontribusi lainnya terdapat pada kenyamanan anak dalam mengenali kosakata yang ada ada pada metode studi ini. Maka metode sosiodrama digunakan pada penelitian ini sebagai metode untuk meningkatkan bahasa anak dimana terjadi interaksi didalamnya Studi ini menemukan bahwa metode sosiodrama berkontribusi positif dalam menstimulasi kemampuan bahasa anak. Adapun implikasi yang dapat dieksplor adalah kemampuan bahasa anak bisa distimulasi dengan metode sosiodrama, terlebih pada kosakata yang berkaitan dengan pengungkapan ekspresi dan perasaan pada anak. Keterbatasan pada penelitian ini terletak pada besaran sampel yang diperoleh secara online dikarenakan kendala Covid 19. Desain eksperimen disarankan untuk penelitian selanjutnya, sehingga keefektifan metode sosiodrama bisa diterapkan secara langsung.

\section{DAFTAR PUSTAKA}

Beaty, J.J. 2015. Observasi Perkembangan Anak Usia Dini (Edisi Ketujuh). Jakarta: Kencana.

Dhieni, Nurbiana, dkk. 2014. Metode Pengembangan Bahasa. Jakarta: Pusat Penerbitan Universitas Terbuka.

Goyena, Rodrigo, and A. Fallis. 2019. Journal of Chemical Information and Modeling 53(9):168999.

Hurlock, Elizabeth B. (2013). Perkembangan Anak Jilid Satu. Edisi Keenam. Jakarta: Erlangga.

Jogiyanto. (2014). Pedoman Survei Kuesioner. Yogyakarta: BPFE Yogyakarta.

Nurkholiq R. N. (2017). Efektifitas Penerapan Metode Sosiodrama Meningkatkan Kecerdasan Kinestik Siswa Dalam Pembelajaran Ips (Penelitian Kuasi Eksperimen Terhadap Siswa Kelas Viii-2 Smp Negeri 9 Bandung Tahun Ajaran 2015/2016). International Journal Pedagogy of Social Studies, 1(1), 100-118.

Otto, Beverly. (2015). Perkembangan Bahasa Pada Anak Usia Dini. Jakarta: Prenadamedia Group.

Pelletier. (2011). Supporting Early Language and Literacy with Sociodramatic Play. Toronto, ON: Scholastic Education.ON: Scholastic Education.

Rajapaksha, P.L.N.R. (2016). Schaffolding Sociodramatic Play in the Preschool Classroom: The Teacher's Role. Mediterranean Journal of Social Sciences, 7(4) 689-694.

Rakhmawati, Nur Ika Sari. (2017). Metode Pengembangan Kemampuan Bahasa Anak. Surabaya: Unesa University Press.

Stone, Randi. (2013). Cara-cara terbaik untuk mengajar reading. Jakarta: PT Indek

Sudarma, Purnami, dan Garminah. (2014). Pengaruh Sosiodrama terhadap Kemampuan Bahasa Lisan siswa SD. e-Journal Mimbar PGSD Universitas Pendidikan Ganesha Jurusan PGSD 2(1). 114120. No:1
Sudjana, N. (2014). Dasar-Dasar Proses Belajar Mengajar. Bandung: Sinar Baru.

Sugiyono. (2011). Statistik Untuk Penelitian. Alfabeta: Bandung.

Sujiono, Yuliani Nurani \& Sujiono, Bambang. (2013). Bermain Kreatif Berbasis Kecerdasan Jamak. Jakarta: PT Indeks.

Susanto, Ahmad. (2017). Perkembangan Anak Usia Dini: Pengantar Dalam Berbagai Aspeknya Edisi Pertama. Jakarta: Kencana Prenada Media Group.

Tarnoto, Nissa. (2013). Modul Bermain Peran. Journal of Chemical Information and Modeling 53(9):1689-99.

Trisnawaty, I. K. A. P. \& I. G. A. O. N. (2017). Pengaruh Metode Sosiodrama Bermuatan Cerita Rakyat Terhadap Kemampuan Berbicara Pada Anak Fakultas Ilmu Pendidikan Universitas Pendidikan Ganesha e-Journal Pendidikan Anak Usia Dini Universitas Pendidikan Ganesha Jurusan Pendidikan Guru Pendidikan Anak Us. Jurnal Pendidikan Anak Usia Dini Undiksha, 5(1), 147-156 